\title{
A Partial Host Range of the High Plains Virus of Corn and Wheat
}

Dallas L. Seifers, Associate Professor, Kansas State University, Agricultural Research Center-Hays, Hays 676019228; Tom L. Harvey, Professor, Department of Entomology, Kansas State University, Manhattan 66506; T. J. Martin, Professor, Kansas State University, Agricultural Research Center-Hays; and Stanley G. Jensen, USDAARS, University of Nebraska, Lincoln 68583-0722

\begin{abstract}
Seifers, D. L., Harvey, T. L., Martin, T. J., and Jensen, S. G. 1998. A partial host range of the High Plains virus of corn and wheat. Plant Dis. 82:875-879.

Barley (Hordeum vulgare), cheat (Bromus secalinus), corn (Zea mays), oat (Avena sativa), rye (Secale cereale), and wheat (Triticum aestivum) were infected by a Kansas isolate of the High Plains virus (HPV) in greenhouse experiments, but several other grass species were not. Infection of a host was dependent upon wheat curl mite numbers. Although both green foxtail (Setaria viridis) and yellow foxtail (S. glauca) are found naturally infected by HPV, only yellow foxtail could be infected in greenhouse experiments. Field sampling (1994 to 1996) of symptomatic yellow foxtail showed that it is a good indicator of the presence of HPV, with 252 of 278 symptomatic plants testing positive in enzyme-linked immunosorbent assay (ELISA) for HPV, 2 of 278 for American wheat striate mosaic virus, and 1 of 278 for johnson grass mosaic virus, whereas 23 of 278 symptomatic plants were negative for all viruses tested by ELISA and were not infectious in back-assays.
\end{abstract}

A new disease of corn and wheat was first observed in 1993 in the High Plains of Texas, Idaho, Kansas, and Colorado (4). A unique $32-\mathrm{kDa}$ protein, seen in sodium dodecyl sulfate-polyacrylamide gel electrophoresis (SDS-PAGE), was associated with infected corn and wheat plants. Thread-like particles were seen in purified preparations, whereas double membranebound bodies were seen in cells infected with the causal agent named the High Plains virus (HPV). The wheat curl mite (Aceria tosichella Keifer; WCM) is the vector of HPV (15). It also has been reported as the vector of wheat streak mosaic virus (WSMV; 18), wheat spot mosaic virus (19), and the wheat spot chlorosis pathogen $(9,10)$; none reportedly have a $32-\mathrm{kDa}$ protein. Although no antisera exist to the wheat spot mosaic pathogen or the wheat chlorosis pathogen, so serological studies of these pathogens are incomplete, partial host range information is available for these pathogens $(9,10,19)$. Because only maize, barley, and wheat had been confirmed as hosts for HPV (15), we tested a greater range of plants for susceptibility to HPV to determine if the experimental

Corresponding author: D. L. Seifers E-mail: dseifers@oz.oznet.ksu.edu

Contribution No. 98-133-J from the Kansas Agricultural Experiment Station. Research was supported in part by a grant from the Kansas Wheat Commission.

Accepted for publication 17 April 1998.

Publication no. D-1998-0526-01R

(C) 1998 The American Phytopathological Society host ranges of HPV and wheat spot mosaic virus, and the wheat chlorotic spot pathogen, were different.

\section{MATERIALS AND METHODS}

Sources of antiserum and cross-absorption and testing of HPV antiserum. Antiserum against HPV was processed and used as reported (15). Antisera to WSMV (16), maize dwarf mosaic virus (MDMV; 12), sugarcane mosaic virus strain MDMVB (SCMV-MDMV-B; 12), and Agropyron mosaic virus (11) were prepared as described. Antiserum (PV 47) to brome mosaic virus was obtained from the American Type Culture Collection. Antiserum to the American wheat striate mosaic virus (AWSMV) was obtained from R. C. Sinha (Ottawa, Ontario, Canada) and used as described (13).

Indirect enzyme-linked immunosorbent assay. The procedure was as described (16). Leaf tissue in all studies was ground at 1:30 (wt:vol) dilution in $0.05 \mathrm{M}$ carbonate buffer, pH 9.6 (coating buffer; 2), and antiserum to HPV was used at a 1:50,000 dilution made from the 1:100 cross-absorbed stock in enzyme-linked immunosorbent assay (ELISA) blocking buffer as described (15). The antirabbit antibody: alkaline phosphatase conjugate $(1: 3,000$, vol:vol; Sigma Chemical Co., St. Louis) and WSMV antibodies (1:1000 vol:vol from a $1 \mathrm{mg} / \mathrm{ml}$ stock solution) were diluted using ELISA blocking buffer. All samples, antibody solutions, and substrate solutions were used at a $200-\mu \mathrm{l}$ volume. Substrate (p-nitrophenyl phosphate, 0.714 $\mathrm{mg} / \mathrm{ml}$ ) in substrate buffer (2) was added to plates which were incubated at room temperature, and the absorbance $\left(405_{\mathrm{nm}}\right)$ was measured after $30 \mathrm{~min}$ (Titertek Mulitskan microelisa plate reader, Flow Laboratories, Inc., McLean, VA).

Infectivity assays. Plants (2-leaf stage) of "Spirit" sweet corn (Zea mays L.; Rogers Seed Co., Boise, ID), "Westford" barley (Hordeum vulgare L.), yellow foxtail (Setaria glauca (L.) Beauv.), "Lodi" oat (Sativa avena L.), "Bonel" rye (Secale cereal L.), "Golden Acres TE7" sorghum (Sorghum bicolor (L.) Moench.), and "Tomahawk" wheat (Triticum aestivum L.) were inoculated manually with 1:10 (wt:vol) extracts as described (14). Inoculated plants were grown in a greenhouse under natural light at 17 to $32^{\circ} \mathrm{C}$.

Maintenance of WCM and infestation of plants. Wheat curl mites (Kansas culture) were of the same source and maintained on Tomahawk wheat as described (15). Plants used as a source for WCM for HPV acquisition were assayed by ELISA for HPV and WSMV prior to use. Identity of WCM used in this study as Aceria tosichella was confirmed by $\mathrm{J}$. W. Amrine (West Virginia University, Morgantown).

To acquire HPV, leaf pieces from WCM-infested wheat (negative in ELISA for HPV and WSMV) were clipped to HPV source plants (Westford barley), and WCMs were allowed a 24-h acquisition access period. WCMs were then transferred manually (using a hair glued to a wooden dowel) from HPV-infected source plants to the test hosts. The WCM and HPV source plants and test plants were covered with plastic cages before and after infestation, as described (15).

Minipurification, SDS-PAGE, estimation of relative molecular masses, and Western blotting of proteins. Extraction and minipurification of HPV protein followed the procedure of Lane $(6,7)$, and relative molecular masses were calculated from densitometry measurements described (16). The method of Laemmli (5) was used for SDS-PAGE.

Electrophoretic analyses were conducted at least twice using extracts from different plants for each species tested. Healthy plant tissue samples were treated and tested identically to test samples for all determinations

For Western blotting, plant extractions and separations by SDS-PAGE and transfer of proteins onto nitrocellulose membranes were done as described (14). Alkaline phosphatase antirabbit goat antibody was 
used for immunoblotting as described by Bollig and Edelstein (1).

Field sampling of yellow foxtail and other species. Plants were collected and placed individually in self-sealing plastic bags. Bags were held in a cooler and transported to the laboratory for processing in ELISA and infectivity assays.

Host range. Grasses and sources of seed used in host range studies are listed in Table 1. Grasses were planted into soil-filled "plant cells" (Stuewe \& Sons, Corvallis, OR) and were infested at the 2-to 3-leaf stage with WCMs as described above. Following infestation, the plants were held in a greenhouse under natural lighting at 18 to $32^{\circ} \mathrm{C}$, rated for symptoms 28 days after infestation, then tested by ELISA against HPV and WSMV antiserum as described above. Symptomatic plants were tested individually, and nonsymptomatic plants were bulked. Barley plants infested with WCMs that had fed on HPV-infected plants served as HPV-positive controls, and barley and test plants infested with WCMs that had fed only on healthy wheat served as HPV-negative controls. A test was considered valid for HPV transfer when at least one barley control plant became infected by HPV. Each species was tested in three experiments to determined if it could be infected by HPV.

Table 1. Names and seed sources of plants used in High Plains virus host range experiments

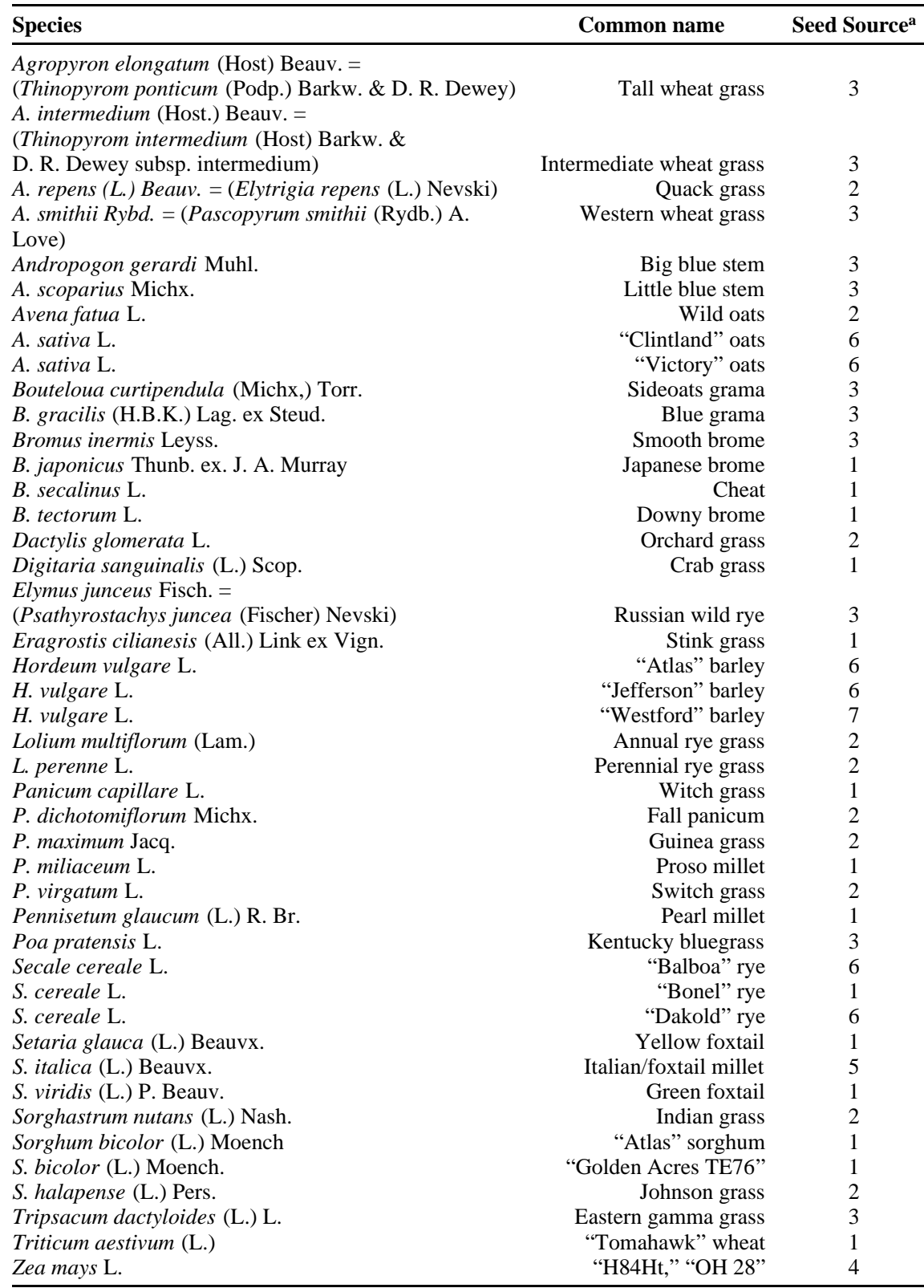

a 1 = Kansas State University Agricultural Experiment Station-Hays, Kansas; plant identity was established by The Great Plains Flora Association (3). 2 = Valley Seed Service, Fresno, CA 93791. 3 = Sharp Bros. Seeds, Healy, KS 67850. 4 = Ohio Agricultural Research and Development Center, Wooster 44691. 5 = Dr. David Baltensperger, University of Nebraska, Scottsbluff 69361. $6=$ National Small Grains Collection, USDA-ARS Aberdeen, Idaho 83210. 7 = Townsend Seeds, Inc., Townsend, MT 59644.

\section{RESULTS AND DISCUSSION}

In initial experiments, each plant was infested with 5 WCMs. This was similar to the number used in studies of WSMV (19) and the wheat spot mosaic pathogen $(9,10)$. Infesting with approximately 50 WCMs per plant (+ or $-10 \mathrm{WCMs}$ ) resulted in infection in "Victory" oats ( 2 of 15 plants in three experiments), cheat (4 of 15 plants in three experiments), and "Dakold" rye (1 of 15 plants in three experiments), indicating that larger numbers of WCMs were needed for transmission in the host range test. Therefore, all species were infested with approximately $50 \mathrm{WCMs}$ per plant. Plants in the field may become infected by HPV because natural WCM infestations can far exceed the 50 per plant used in this study. In addition, variation among HPV isolates, strains of host tested, and WCMs also might affect host range of the HPV at different locations.

The host range determined for HPV differed from those reported for WSMV (19) and the wheat spot chlorosis pathogen (9,10; Table 2). The HPV infected cheat (Bromus secalinus L.), barley, maize, Victory oat, rye, and wheat, but it differed from the other pathogens by not infecting stink grass, witch grass, fall panicum, proso millet, switch grass, johnson grass, and "Atlas" sorghum. The HPV-infected oat, cheat, barley, rye, and wheat all exhibited mosaic symptoms interspersed with chlorotic spots. Occasionally, chlorotic spots appeared on control plants infested with pathogen-free WCMs. Some plants of each species testing positive in ELISA also were minipurified, and the extracts were separated by SDS-PAGE with a counterpart gel being used for Western blotting. A 33-kDa band was present in the SDSPAGE, and this band reacted to the HPV probe in Western blots (data not shown). Unless otherwise stated, the positive threshold for ELISA was set at 0.100 , because at this level of response the 33$\mathrm{kDa}$ band could be identified consistently in SDS-PAGE and by Western blotting (16).

Other species tested, but not infected by HPV, included tall wheat grass (Agropyron elongatum $=$ Thinopyrum ponticum (Podp.) Barkw. \& D.W. Dewey), intermediate wheat grass (Agropyron intermedium = Thinopyrum intermedium (Host) Barkw. \& D. R. Dewey subsp. intermedium), indian grass (Sorghastrum nutans (L.) Nash.), quack grass (Agropyron repens $=$ Elytrigia repens (L.) Nevski), big blue stem (Andropogon gerardi Muhl.), little blue stem (A. scoparius Michx.), sideoats grama (Bouteloua curtipendula (Michx.) Torr.), blue grama (B. gracilis (H.B.K.) Lag. ex Steud.), Russian wild rye (Elymus junceus $=$ Psathyrostachys juncea (Fischer) Nevski), annual rye grass (Lolium multiflorum L.), pearl millet (Pennisetum glaucum L.), and eastern gama grass (Tripsacum dactyloides (L.) L.). None tested positive 
in ELISA for HPV or WSMV in any of three experiments.

In 1994, yellow foxtail (10 plants) and green foxtail (4 plants) exhibiting mosaic symptoms in the field tested positive in ELISA for HPV and contained a $33-\mathrm{kDa}$ band in SDS-PAGE (data not shown). The yellow foxtail, reported immune to WSMV

Table 2. Comparison of the experimental host ranges (greenhouse experiments) of the wheat curl mite-vectored wheat spot mosaic pathogen (WSMp), wheat spot chlorosis pathogen (WSCp), and the High Plains virus (HPV)

\begin{tabular}{|c|c|c|c|c|}
\hline \multirow[b]{2}{*}{ Host } & \multirow[b]{2}{*}{ Common name or variety } & \multicolumn{3}{|c|}{ Pathogen } \\
\hline & & WSMp $^{\mathbf{a}}$ & WSCp $^{b}$ & HPV \\
\hline Avena fatua & Wild oats & $-{ }^{c}$ & $\mathrm{NT}^{\mathrm{d}}$ & - \\
\hline A. sativa & Clintland oats & - & - & - \\
\hline A. sativa & Victory oats & - & NT & $+^{\mathrm{e}}$ \\
\hline Bromus inermis & Smooth brome & NT & - & - \\
\hline B. japonicus & Japanese brome & - & NT & - \\
\hline B. secalinus & Cheat & - & NT & + \\
\hline B. tectorum & Downy brome & - & NT & - \\
\hline Dactylis glomerata & Orchard grass & NT & + & - \\
\hline Digitaria sanguinalis & Crab grass & - & + & - \\
\hline Echinochloa crusgalli & Barnyard grass & - & - & - \\
\hline Eragrostis cilianensis & Stink grass & + & NT & - \\
\hline Hordeum vulgare & Westford barley & NT & NT & + \\
\hline H. vulgare & Atlas & + & NT & NT \\
\hline H. vulgare & Jefferson & NT & + & NT \\
\hline Lolium perenne & Perennial rye grass & NT & - & - \\
\hline Panicum capillare & Witch grass & NT & + & - \\
\hline P. dichotomiflorum & Fall panicum & NT & + & - \\
\hline P. miliaceum & Proso millet & - & + & - \\
\hline P. virgatum & Switch grass & NT & + & - \\
\hline Poa pratensis & Kentucky bluegrass & NT & - & - \\
\hline Secale cereale & Dalkold rye & + & NT & - \\
\hline S. cereale & Balboa rye & NT & + & - \\
\hline S. cereale & Bonel rye & NT & NT & + \\
\hline Setaria glauca & Yellow foxtail & NT & NT & + \\
\hline S. italica & Hungarian millet & + & NT & - \\
\hline S. magna & & + & + & NT \\
\hline S. veriticillata & Bristly foxtail & + & NT & NT \\
\hline S. virdis & Green foxtail & + & NT & - \\
\hline Sorghum halepense & Johnson grass & NT & + & - \\
\hline S. bicolor & Atlas & NT & + & - \\
\hline Triticum aestivum & Kharkov & + & NT & NT \\
\hline T. aestivum & Cheyenne & NT & + & NT \\
\hline T. aestivum & Tomahawk wheat & NT & NT & + \\
\hline Zea mays & Golden rush & + & NT & NT \\
\hline Z. mays & $\mathrm{OH} 28$ & NT & + & + \\
\hline
\end{tabular}

a Citation 19.

b Citations 9 and 10 .

$\mathrm{c}_{-}=$no symptoms reported for WSMp and WSCp. For HPV, the plants were negative in enzymelinked immunosorbent assay (ELISA).

${ }^{\mathrm{d}} \mathrm{NT}=$ not tested.

e For WSMp and WCSp, $+=$ the plants developed symptoms. For the HPV, $+=$ the plant was positive in ELISA ( 0.100 or greater) and a $33-\mathrm{kDa}$ band was also present in minipurified extracts separated by sodium dodecyl sulfate-polyacrylamide gel electrophoresis or in Western blots.

$(17,20)$, was negative in ELISA against antiserum to WSMV, MDMV, SCMVMDMV-B, johnson grass mosaic virus, Agropyron mosaic virus, brome mosaic virus, and American wheat striate mosaic virus (AWSMV) and was not infectious by mechanical transmission to wheat. Yellow foxtail was not tested as a host for WSMV (19) or the wheat spot chlorosis pathogen $(9,10)$. When green foxtail tested positive for HPV, it also routinely tested positive for WSMV. Green foxtail is listed as a host for WSMV (19) but was not tested in the wheat spot chlorosis pathogen studies $(9,10)$.

Yellow foxtail seedlings (2-leaf stage; seed source from Kansas State University$\mathrm{ARCH})$ were infested with WCMs (50/plant) that had fed on HPV-positive Westford barley. In these experiments 7 of 20,1 of 10 , and 4 of 15 yellow foxtail plants were symptomatic, respectively, and extracts from symptomatic plants tested positive in ELISA for HPV. Subsequent experiments were conducted using nonviruliferous WCMs to infest the HPV-infected yellow foxtail from the first (one source plant HPV ELISA $=0.616)$ and third of the earlier experiments (one source plant HPV ELISA $=0.255$ ). These WCMs (50/plant) were then used to infest 20 yellow foxtail plants and 10 Westford barley plants in each of two experiments. In the first experiment, 2 yellow foxtail and 3 barley plants tested positive for HPV; in the second experiment, 1 yellow foxtail and 2 barley plants tested positive in ELISA for HPV. These results demonstrated that the WCMs can acquire HPV from yellow foxtail and subsequently transmit HPV to yellow foxtail and Westford barley. Although naturally infected green foxtail from the field had a 33-KDa band in SDS-PAGE and Western blots (data not shown), it could not be infected with HPV in three greenhouse experiments, using either a culture of HPV or HPV mixed with WSMV, even though it was infected by WSMV from the mixed

Table 3. Number of symptomatic yellow foxtail plants testing positive ${ }^{\mathrm{a}}$ in enzyme-linked immunosorbent assay (ELISA) ${ }^{\mathrm{b}}$ against antiserum ${ }^{\mathrm{c}}$ made against the High Plains virus (HPV)

\begin{tabular}{|c|c|c|c|c|c|c|c|c|}
\hline \multirow[b]{2}{*}{ Variable } & \multicolumn{8}{|c|}{ Sample date } \\
\hline & 6 Jul 95 & 14 Jul 95 & 16 Aug 95 & 24 Aug 95 & 17 Jul 96 & 22 Aug 96 & 16 Sep 96 & 23 Sep 96 \\
\hline Number yellow foxtail samples & 1 & 4 & 26 & 33 & 18 & 67 & 192 & 1 \\
\hline HPV-infected & 1 & 4 & 24 & 20 & 16 & 60 & 176 & 0 \\
\hline AWSMV-infected ${ }^{\mathrm{d}}$ & $\ldots^{\mathrm{e}}$ & $\ldots$ & $\ldots$ & $\ldots$ & 2 & 0 & 0 & 0 \\
\hline JGMV-infected ${ }^{\mathrm{d}}$ & $\ldots$ & $\ldots$ & $\ldots$ & $\ldots$ & 0 & 0 & 0 & 1 \\
\hline No reaction to antisera & 0 & 0 & 2 & 13 & 0 & 7 & 16 & 0 \\
\hline Minimum positive ELISA value & 0.100 & 0.100 & 0.050 & 0.050 & 0.100 & 0.054 & 0.050 & 0.100 \\
\hline \multicolumn{9}{|c|}{$\begin{array}{l}\text { a Unless otherwise stated, minimum positive thresholds for ELISA were set based on previous work: American wheat striate mosaic virus (AWSMV) was } \\
\text { set at twice the value for the equivalent healthy control (13), HPV at } 0.100 \text { (15), and wheat streak mosaic virus (WSMV) at } 1.4 \text { times the equivalent } \\
\text { healthy control (15). } \\
\text { b Samples were also negative in ELISA against WSMV, maize dwarf mosaic virus (MDMV), sugarcane mosaic virus strain MDMV-B, brome mosaic virus, } \\
\text { AWSMV, and Agropyron mosaic virus antisera. } \\
\text { c All samples not testing positive in ELISA against any antisera also were not infectious when mechanically (finger) inoculated onto "Westford" barley, } \\
\text { "Country Gentleman" corn, "Lodi" oat, "Bonel" rye, and "Tomahawk" wheat. } \\
\text { d JGMV = Johnsongrass mosaic virus. } \\
\text { e ... = not tested. }\end{array}$} \\
\hline
\end{tabular}



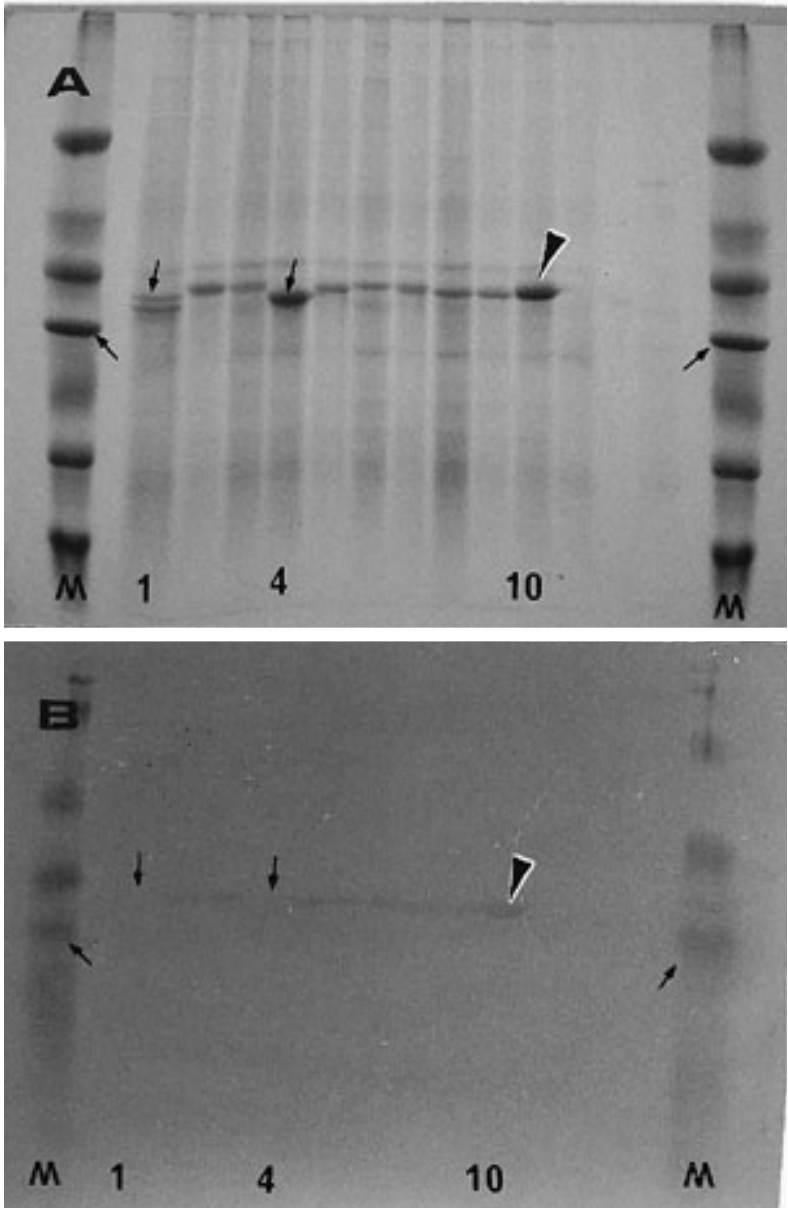

Fig. 1. High Plains virus (HPV) protein concentrated from yellow foxtail by minipurification and (A) separated by sodium dodecyl sulfate-polyacrylamide gel electrophoresis (SDS-PAGE); stained with Coomassie blue $(0.125 \%$ Coomassie blue R-250, 50\% methanol, and $10 \%$ acetic acid); and (B) probed with antibodies to HPV (1:25,000 dilution) and antirabbit goat antibody:alkaline phosphatase conjugate (1:3,000 dilution/Bio-Rad 170-6518) in a Western blot. (A) SDS-PAGE gel counterpart to that used for Western blot. Lanes 1 and 4, symptomatic yellow foxtail, negative in ELISA to HPV; lanes 2, 3, and 5 to 9, symptomatic yellow foxtail positive in ELISA for HPV; lane 10, HPV positive control (white outlined arrowhead); lane 11, healthy yellow foxtail; lane 12, healthy Westford barley; and lane 13, healthy wheat. Both lane M, molecular mass markers as described for gel A of Fig. 1A. Arrow marks position of 29-kDa protein. (B) Western blot of gel loaded identically to counterpart gel (A). Arrow in lanes 1 and 4 indicates lack of binding of HPV probe to bands seen in lanes 1 and 4 of counterpart gel in (A). Lane M on left side loaded with prestained markers as described for gel B of Fig.1. Arrow indicates position of 32.5-kDa marker. Arrow in lane $\mathrm{M}$ on right side of gel marks the position of 31-kDa marker for Kaleidoscope prestained markers as described for Fig. 1B. Electrophoresis was in a $10 \%$ gel, $0.75 \mathrm{~mm}$ thick. Duration of electrophoresis was 3 h 20 min (SE600 tank, Hoefer Scientific, Instruments San Francisco) with volts and mA set at 400 and 30, respectively. Western blotting was done in a TE 50 Transphor Unit (Hoefer Scientific Instruments, San Francisco) at $100 \mathrm{~V}$ for $1 \mathrm{~h}$.

culture. The foxtail data neither prove nor disprove a relationship of HPV to WSMV or the wheat spot chlorosis pathogen. The relationship remains speculative pending culture of the other two pathogens. Our inability to infect green foxtail in greenhouse experiments may represent variability in WCMs and their ability to transmit HPV to different hosts.

Yellow foxtail was the only species found singly infected by HPV in 1994 field tests, and was thought, therefore, to be an indicator of HPV in the field. To examine this hypothesis, yellow foxtail was assayed during 1995 and 1996 field tests to determine the reliability of using it as an HPV indicator. In 1995, field samples of only yellow foxtail collected at four different the counterpart gel stained with Coomassie blue R-250, lanes 1 through 10 show bands of approximately 32 to $33 \mathrm{kDa}$ not present in the extract from healthy yellow foxtail (lane 11) but with similar locations to those of the HPV control in lane 10 (white outlined arrowhead; Fig. 1A). The plants used for extracts in lanes 1 (doublet bands) and 4 (single band) were negative in ELISA for HPV, and those in lanes 2, 3, and 5 through 9 were positive in ELISA for HPV. Lanes 12 and 13 contain extracts from healthy barley and wheat, respectively. The ELISA values for extracts (1:30, wt:vol) in lanes 1 through 10 were $0.031,0.114,0.118$, $0.025,0.113,0.164,0.127,0.165,0.115$, and 0.232 , respectively, and 0.006 for the extract from healthy yellow foxtail (lane 11). When tested in Western blotting, the bands in lanes 1 and 4 of the counterpart gel (arrows) did not react to the HPV probe, whereas the 33-kDa protein (white outlined arrowhead) from tissue positive in HPV did react to the probe, as did the bands from the other ELISA-positive samples for HPV (Fig. 1B). The mosaic symptoms of the plants in lanes 1 and 4 and the bands seen in SDS-PAGE (Fig. 1A) could result from a different pathogen or a serotype of HPV. The plants from which the extracts were obtained were small because of drought conditions and subsequently died before attempts could be made to isolate a pathogen from these samples. Tissue in the last two samples having ELISA values of 0.054 and 0.050 reacted to the HPV probe in Western blotting; therefore, the minimum threshold for these two sampling periods was lowered to those values, and symptomatic plants reacting in Western blots were included with the total number of plants with values of 0.100 or greater.

On 20 August 1995, yellow foxtail and symptomatic green foxtail, witch grass, stink grass, crab grass, and prairie cup grass plants adjacent to symptomatic yellow foxtail were sampled at two different locations (Table 4). At location 1, 18 of 20 yellow foxtail were positive for HPV and 2 were negative in ELISA. Of the symptomatic species near these yellow foxtail plants, only green foxtail tested positive for HPV and, in each instance, it also was infected by WSMV. Witch grass was infected by WSMV and AWSMV, and the stink grass and crab grass by WSMV. At location 2, 20 of 29 yellow foxtail plants tested positive for HPV and 9 were negative in ELISA. Among other species at location 1 , only green foxtail tested positive for HPV, and each HPV-positive plant was also positive for WSMV. The remaining 53 green foxtail plants tested positive for WSMV only. Witch grass was infected either by WSMV or AWSMV, as at location 1. All prairie cup grass plants were infected only by WSMV.

In 1996, 278 symptomatic yellow foxtail were sampled from the field, of which 252 
Table 4. Numbers of plants testing positive ${ }^{\mathrm{a}}$ in enzyme-linked immunosorbent assay (ELISA) ${ }^{\mathrm{b}}$ against antisera made to High Plains virus (HPV), wheat streak mosaic virus (WSMV), and American wheat striate mosaic virus (AWSMV) at two different locations in the field on 20 August 1995

\begin{tabular}{|c|c|c|c|c|c|c|c|}
\hline \multirow[b]{2}{*}{ Location } & \multirow[b]{2}{*}{ Species } & \multirow[b]{2}{*}{ Total plants } & \multicolumn{4}{|c|}{ ELISA } & \multirow[b]{2}{*}{ No reaction } \\
\hline & & & HPV & WSMV & HPV/WSMV & AWSMV & \\
\hline \multirow[t]{5}{*}{1} & Yellow foxtail & 20 & 18 & 0 & 0 & 0 & 2 \\
\hline & Green foxtail & 23 & 0 & 16 & 7 & 0 & 0 \\
\hline & Witch grass & 8 & 0 & 2 & 0 & 6 & 0 \\
\hline & Stink grass & 1 & 0 & 1 & 0 & 0 & 0 \\
\hline & Crab grass & 2 & 0 & 2 & 0 & 0 & 0 \\
\hline \multirow[t]{4}{*}{2} & Yellow foxtail & 29 & 20 & 0 & 0 & 0 & 9 \\
\hline & Green foxtail & 62 & 0 & 53 & 9 & 0 & 0 \\
\hline & Witch grass & 25 & 0 & 5 & 0 & 20 & 0 \\
\hline & Prairie cup grass & 14 & 0 & 14 & 0 & 0 & 0 \\
\hline
\end{tabular}

${ }^{a}$ Minimum positive thresholds for ELISA were set based on previous work: AWSMV was set at twice the value for the equivalent healthy control (13), HPV at 0.100 (15), and WSMV at 1.4 times the equivalent healthy control (15).

b All samples not testing positive in ELISA against any antisera also were not infectious when mechanically (finger) inoculated onto "Westford" barley,

"Country Gentleman" corn, "Lodi" oat, "Bonel" rye, and "Tomahawk" wheat.

(90.6\%) tested positive in ELISA for HPV; 2 tested positive for AWSMV (ELISA values of 0.887 and 0.511 , respectively; healthy control 0.081 ) and 16 plants $(8 \%)$ were negative in ELISA (Table 3). The single symptomatic yellow foxtail plant testing positive against johnson grass mosaic virus antiserum was negative for HPV. Extract (1:10, wt:vol) from this yellow foxtail plant was infectious to sorghum and oat. The resulting symptomatic sorghum and oat tested positive against only johnson grass mosaic virus antiserum. Yellow foxtail has not been reported as a host for johnson grass mosaic virus (8). All symptomatic yellow foxtail testing negative in ELISA (value below 0.100) were tested by minipurification and Western blotting. Plants with ELISA values as low as 0.054 reacted in Western blots to the HPV probe. Thus, for that particular set of samples, the positive ELISA threshold was set at 0.054, and samples having ELISA values at or above this value and positive in Western blotting were rated as positive for HPV infection. At the last sampling, the minimum threshold was lowered to 0.050 based on Western blots. One sample testing negative in ELISA for HPV and WSMV again had a doublet of bands migrating in the same position with respect to the HPV 33-kDA band as observed in 1995 (Fig. 1A), and again this doublet did not react to the HPV probe in Western blotting (data not shown). In addition, one sample also had a single band in SDS-PAGE with a relative mass of approximately $39 \mathrm{kDa}$, which did not react in Western blotting (data not shown). These two samples and all yellow foxtail plants testing negative in ELISA were not infectious when used to mechanically inoculate yellow foxtail, corn, barley, oat, rye, sorghum, and wheat.
Our results indicate that hosts of the HPV include cheat, corn, barley, oat, rye, green foxtail, yellow foxtail, and wheat. Infection of cheat, oat, and rye was dependent upon the number of WCM used to infest them. In the field, green foxtail was found naturally infected by both HPV and WSMV. Yellow foxtail also was found infected naturally by HPV in the field, but never by WSMV. Yellow foxtail was infected by HPV in greenhouse experiments using WCMs, but green foxtail was not. Three years of field testing of symptomatic yellow foxtail indicated that it is a good indicator of HPV. Since yellow foxtail is immune to WSMV $(17,20)$, it may also be a source for obtaining pure cultures of HPV.

\section{ACKNOWLEDGMENTS}

We thank J. Ackerman for his excellent technical assistance, particularly during the electrophoresis and Western blotting phases of this work.

\section{LITERATURE CITED}

1. Bollig, D. M., and Edelstein, S. J. 1991. Immunoblotting. Pages 181-208 in: Protein Methods. Wiley-Liss, New York.

2. Clark, M. F., and Adams, A. N. 1977. Characteristics of the microplate method of enzyme-linked immunosorbent assay for the detection of plant viruses. J. Gen. Virol. 34:475-483.

3. Great Plains Flora Association. 1991. Flora of the Great Plains. University Press of Kansas, Lawrence.

4. Jensen, S. G., Lane, L. C., and Seifers, D. L. 1996. A new disease of maize and wheat in the high plains. Plant Dis. 80:1387-1390.

5. Laemmli, U. K. 1970. Cleavage of structural proteins during the assembly of head of bacteriophage T4. Nature 227:680-685.

6. Lane, L. C. 1978. A simple method for stabilizing protein-sulfhydryl groups during SDS-gel electrophoresis. Anal. Biochem. 86:655-664.

7. Lane, L. C. 1986. Propagation and purification of RNA plant viruses. Methods Enzymol. 118:687-696

8. McDaniel, L. L., and Gordon, D. T. 1985.
Identification of a new strain of maize dwarf mosaic virus. Plant Dis. 69:602-607.

9. Nault, L. R., and Styer, W. E. 1970. Transmission of an eriophyid-borne wheat pathogen by Aceria tulipae. Phytopathology 60:16161618.

10. Nault, L. R., Styer, W. E., Gordon, D. T., Bradfute, O. E., Lafever, H. N., and Williams, L. E. 1970. An eriophyid-borne pathogen from Ohio and its relation to wheat spot mosaic virus. Plant Dis. Rep. 54:156-160.

11. Seifers, D. L. 1992. Partial characterization of a Colorado isolate of Agropyron mosaic virus. Plant Dis. 76:564-569.

12. Seifers, D. L., and Caceres, J. 1988. Titer variation in infected sorghum differing in resistance to maize dwarf mosaic virus strain-B. Phytopathology 78:208-212.

13. Seifers, D. L., Harvey, T. L., and Bowden, R. L. 1995.Occurrence and symptom expression of American wheat striate mosaic virus in wheat in Kans. Plant Dis. 79:853-858.

14. Seifers, D. L., Harvey, T. L., Kofoid, K. D. and Stegmeier, W. D. 1996. Natural infection of pearl millet and sorghum by wheat streak mosaic virus in Kansas. Plant Dis. 80:179-185

15. Seifers, D. L., Harvey, T. L., Martin, T. J., and Jensen, S. G. 1997. Identification of the wheat curl mite as the vector of the High Plains virus of corn and wheat. Plant Dis. 81:1161-1166.

16. Seifers, D. L., Martin, T. J., Harvey, T. L., and Gill, B. S. 1995. Temperature sensitivity and efficacy of wheat streak mosaic virus resistance derived from Agropyron intermedium. Plant Dis. 79:1104-1106.

17. Sill, W. H., Jr., and Connin, R. V. 1953. Summary of the known host range of wheat streak mosaic virus. Trans. Kans. Acad. Sci. 56:411-417.

18. Slykhuis, J. T. 1955. Aceria tulipae Keifer (Acarina:Eriophyidae) in relation to the spread of wheat streak mosaic. Phytopathology 45:116-128.

19. Slykhuis, J. T. 1956. Wheat spot mosaic, caused by a mite-transmitted virus associated with wheat streak mosaic. Phytopathology 46:682-687.

20. Somensen, H. W., and Sill, W. H., Jr. 1970. The wheat curl mite, Aceria tulipae Keifer, in relation to epidemiology and control of wheat streak mosaic. Res. Pub. 162, Kans. Agric. Exp. Stn., Manhattan. 